\title{
The importance of the professional competence of forign language teachers
}

\section{Halima MUHAMMADIEVA ${ }^{1}$}

Namangan State University

\begin{tabular}{l} 
ARTICLE INFO \\
\hline Article history: \\
Received April 2021 \\
Received in revised form \\
20 April 2021 \\
Accepted 15 May 2021 \\
Available online \\
25 June 2021 \\
\hline
\end{tabular}

\section{Keywords:}

competence, professional competence of foreign language teacher, qualification.

\begin{abstract}
Today, the process of reforming the teaching of foreign languages has intensified due to the globalization of social, economic and political problems around the world. Teaching and learning foreign languages is becoming a vital necessity for every nation. In modern Uzbekistan, the role of teaching and developing foreign languages, especially English, is currently of great value. Learning English is a necessity of life and is one of the basic requirements of modern society. In this article, the author addresses the problem of the professional competence of foreign language teachers which are necessary for successful pedagogical activity.
\end{abstract}

2181-1415/C) 2021 in Science LLC.

This is an open access article under the Attribution 4.0 International (CC BY 4.0) license (https://creativecommons.org/licenses/by/4.0/deed.ru)

\section{Xorijiy til o'qituvchilarining kasbiy kompetentligining ahamiyati}

\section{Kalit so'zlar:}

kompetensiya,

chet tili o'qituvchisining

kasbiy kompetentligi, malaka.

\section{ANNOTATSIYA}

Bugungi kunda butun dunyoda ijtimoiy, iqtisodiy va siyosiy muammolarning globallashuvi tufayli chet tillarini o'qitishni isloh qilish jarayoni jadallashdi. Chet tillarni o'qitish va o'rganish har bir xalq uchun hayotiy zaruratga aylanib bormoqda. Yangi O'zbekistonda chet tillarini, ayniqsa ingliz tilini o'rgatish va rivojlantirishning roli hozirda juda katta ahamiyatga ega. Ingliz tilini o'rganish hayotning zarurati va zamonaviy jamiyatning asosiy talablaridan biridir. Ushbu maqolada muallif muvaffaqiyatli o'qitish faoliyati uchun zarur bo'lgan chet tili o'qituvchilarining kasbiy kompetentsiyasi muammosiga murojaat qiladi.

\footnotetext{
${ }^{1}$ Senior lecturer, Namangan State University, Namangan, Uzbekistan.

E-mail: halimahon77@mail.ru.
} 


\section{Важность профессиональной компетентности преподавателей иностранного языка}

\author{
Ключевые слова: \\ компетентность, \\ профессиональная \\ компетентность учителя \\ иностранного языка, \\ квалификация.
}

АННОТАЦИЯ

\begin{tabular}{lccr}
\hline \multicolumn{1}{c}{ Сегодня } & процесс & реформирования & \multicolumn{2}{c}{ преподавания } \\
иностранных & языков & активизировался & в связи с \\
глобализацией социальных, экономических и политических \\
проблем во всем мире. Преподавание и изучение иностранных \\
языков становится жизненной необходимостью для каждого \\
народа. В современном Узбекистане большое значение имеет \\
преподавание и развитие иностранных языков, особенно \\
английского. Изучение английского языка является \\
жизненной \\
требований соводимостью и одним из основных \\
обращается к проблеме профессиональной компетентности \\
учителей иностранного языка, необходимой для успешной \\
педагогической деятельности.
\end{tabular}

The professional competence of a teacher is understood as an integral characteristic that determines the ability to solve professional problems arising in real situations in professional activity, the use of knowledge of professional and life experience, values and inclinations. Today, the study and mastery of a foreign language is one of the important requirements in connection with scientific and technological progress, we are increasingly faced with the fact that knowledge of the language is necessary and is an integral factor of success in a multicultural world. The study of foreign languages provides for the development of international cooperation, open access to the achievements of world science and information resources. The recent reforms and the decrees of the president of our country phased improvement of teaching foreign languages, the entire educational system, from preschool to postgraduate education. This is due to the need to improve the system of teaching foreign languages in all fields of science, as well as to train future highly qualified specialists of philologists who are fluent in a foreign language. Professional development is a specially organized purposeful process to expand the level of qualification of a person who has or is receiving secondary professional and higher education, by improving professional competencies in accordance with new socioeconomic, technological conditions and / or Uzbek and international requirements and standards [3].

As many methodological researchers note, modern requirements for a teacher's qualifications include: to training, professional development and retraining of teaching staff. In the professional standard, it is noted that the qualifications of a teacher reflect the level of professional training of a teacher and his competence to work in the field of education. The qualification of a teacher is made up of his professional competencies.

Let's clarify the concepts of "competence" and "qualifications" to understand the requirements of the standard for a teacher, and in particular for a teacher of a foreign language. Oxford Advanced Learners dictionary interprets the word "qualification" as a skill or type of experience that you need for a particular job or activity". "Competence" is a skill that you need in a particular job or for a particular task. Therefore, in order to become a competent teacher of a foreign language, it is necessary to have a certain set of 
competencies that allows him to effectively act in the field of foreign language education and have a certain level of qualifications. Competence is understood by us as the ability of successful activity due to the formed skills and acquired knowledge or a set of competencies necessary for professional activity.

The professional competence of a teacher is understood as an integral characteristic that determines the ability to solve professional problems arising in real situations in professional activity, the use of knowledge of professional and life experience, values and inclinations. The Council of Europe identifies five core competencies required by any specialist today.

In the context of improving the qualifications of foreign language teachers, they acquire special significance.

1. Political and social competences associated with the ability to take responsibility, participate in joint decision-making, and participate in the functioning and development of democratic institutions.

2. Competencies related to life in a multicultural society, designed to prevent the emergence of xenophobia, the spread of a climate of intolerance and promote both the understanding of differences and the willingness to live with people of other cultures, languages and religions.

3. Competencies that determine the proficiency of oral and written communication, important in work and social life to such an extent that those who do not own them are threatened with isolation from society. This group of communication includes proficiency in several languages, which is becoming increasingly important.

4. Competences associated with the emergence of the information society. Possession of new technologies, understanding their strengths and weaknesses, the ability to critically approach information and advertising disseminated through the media and the Internet.

5. Competencies that realize the ability and desire to learn throughout life, not only professionally, but also in personal and social life.

6. Now, we can interpret the above competencies and choose which competences are very necessary for the professional competencies of a foreign language teacher. Thus, the professional competencies of a foreign language teacher include: social, sociolinguistic and communicative.

Social competence implies the willingness and desire to interact with other people, that is, to act in society, taking into account the positions of other people.

Sociolinguistic competence allows you to form the ability to act in accordance with the native and other culture, applying universal human morality, cultural identity and legal knowledge appropriately.

Communicative competence contributes to the entry into communication in order to be understood by others by means of foreign language communication, to communicate through language, transmit thoughts and exchange them in various situations in the process of interacting with other participants in communication. At the same time, it is correct to use the system of linguistic and speech norms and correctly choose the communicative behavior that is adequate to the authentic communicative situations.

In order to develop above-mentioned professional competences, the teacher of foreign language needs to be engaged in self-education, self-monitoring and self-regulation to comply with all requirements of teaching as well. To meet all the requirements that are 
presented today to a foreign language teacher, it is necessary to constantly engage in selfeducation. Self-education can be successfully carried out through distance educational technologies. The features of distance learning technologies include the variety and flexibility of the tools, methods and organizational forms of training used, as well as the differentiation of educational processes in the direction and content, and its leading idea is the desire for constant self-development and self-restoration of the specialist as a subject of activity throughout life. The system of continuous professional development of scientific and pedagogical workers can be represented as a set of personalized distance educational programs (modules/courses, internships) aimed at expanding the level of professional qualification by improving professional competencies in accordance with new requirements and standards.

Currently, educational institutions of higher education in our country are creating a network of multimedia classrooms in a single multi-service interactive educational environment, which allows students to carry out theoretical and practical training using the latest information technologies, quickly access the repositories of educational materials (engineering educational portal, websites of faculties and departments, electronic library, etc.), conduct video conferences, testing, and most importantly, remote access to unique laboratory stands and servers with specialized software is provided.

\section{REFERENCES:}

1. Hayes D. (Ed.). (2014). Innovations in the continuing professional development of English language teachers. London, England: British Council.

2. Gulyamova J., Irgasheva S., \& Bolitho R. (2014). Professional development through curriculum reform: the Uzbekistan experience. the continuing professional development of English language teachers, 45.

3. Khayretdinova A.K., \& Narkulov U.M. (2020). The importance of professional development of foreign language teachers in Uzbekistan. Мировая наука, (7). - PР. 142-150.

4. Jabborov U. (2020). The importance of foreign pedagogical experience in the preparation process of english language teachers. Архив Научных Публикаций JSPI. PP. 1-11.

5. Muhammadiyeva H., \& Ibrohimova M. (2020). Collaborative and individual professional development for English Teachers. Asian Journal of Multidimensional Research (AJMR), 9(5). - PP. 61-64. 